\title{
Perceived knowledge and perceptions toward biostatistics among dental and medical undergraduate students in International Islamic University Malaysia
}

Mohamad Shafiq Mohd Ibrahim ${ }^{*}$, Ain Nadzirah Mohamad Zin² ${ }^{2}$ Hani Zawani Haslim², Muhd Firdaus Che Musa ${ }^{1}$, Syarifah Haizan Sayed Kamar ${ }^{1}$

${ }^{1}$ Department of Paediatric Dentistry and Dental Public Health, Kulliyyah of Dentistry, International Islamic University Malaysia, Kuantan, Pahang, Malaysia

${ }^{2}$ Kulliyyah of Dentistry, International Islamic University Malaysia, Kuantan, Pahang, Malaysia

\begin{abstract}
Research into dental and medical student on biostatistics may inform the educational policy changes. Therefore, it was vital to assess the level of knowledge and perception about biostatistics among dental and medical undergraduate students in order to determine their proficiency in this subject. A cross-sectional study was undertaken among dental and medical undergraduate students in International Islamic University Malaysia, Kuantan. The assessment of perceived and perception toward biostatistics was based on a 5-points Likert scale including 50 questions distributed into five domains to assess the knowledge, course value, difficulty, behavioural and expectations. A total of 158 out of 190 students responded to the questionnaire yielding a response rate of $83.2 \%$. It was observed that more than $70 \%$ of students acknowledged that knowledge gained from biostatistics courses is useful to their future career, and almost $80 \%$ realized the relevance of biostatistics to real health issues. This study concludes that undergraduate dental students have almost similar and moderate level of knowledge in biostatistics as compared to the medical students. However, it is important to have additional practice and training through workshop to improve their level of comprehension in biostatistics.
\end{abstract}

Keywords: biostatistics, dentistry, knowledge, medicine, perception
Received:

10 January 2022

Revised:

11 February 2022

Accepted:

28 February 2022

Published Online:

4 March 2022

How to cite this article:

Mohd Ibrahim, M. S. ., Mohamad Zin, A. N. ., Haslim, H. Z. ., Che Musa, M. F. ., \& Sayed Kamar, S. H. . . Perceived knowledge and perceptions toward biostatistics among dental and medical undergraduate students in International Islamic University Malaysia. IIUM Journal of Orofacial and Health Sciences, 3(1), 111-123. https://doi.org/10.31436/ijohs. v3i1.97

Article DOI:

10.31436/ijohs.v3i1.97

*Corresponding author

Address:

Department of Paediatric and Dental Public Health, Kulliyyah of Dentistry, International Islamic University Malaysia, Kuantan, Pahang, Malaysia.

Telephone: +60 19-943 1436

Email address:

shafiq@iium.edu.my

\section{Introduction}

Biostatistics was often regarded as a field where it was limited to those who had a mathematical background just because the term 'statistics' was associated with mathematics. Only those who were related to the field of statistics and a few of the general population were aware of the important part of biostatistics in dental research and evidence-based practice in dentistry (Sujatha et al., 2018). In the context of health care delivery, nowadays, many clinicians and academicians believe that by reviewing articles related to one's field, it might have an impact on patient care and thus, improving the education in dental and medical research. Having said that, most of the articles to be reviewed were often accompanied by statistics. Hence, it was vital for all dental and medical undergraduate students to acquire the knowledge of 
biostatistics. Moreover, the acknowledgement of evidence-based practice (EBP) in clinical studies and practice also require a thorough understanding of biostatistics knowledge among early researchers in medical or dental studies (Penmetsa et al., 2017).

Pimenta et al. (2015) states that in order to improve statistical skills and knowledge among dental students and practitioners, one should have a positive perception toward biostatistics. Dental students and medical students were very well motivated about the study of their courses but in minor branches such as biostatistics, it was often being disregarded and was insinuated as something of lesser importance (Penmetsa et al., 2017). Consequently, this kind of perception towards biostatistics often leads to cutbacks of permanency in the biostatistics knowledge. Besides that, the assessment and comprehension of biostatistics perception such as general perception towards biostatistics subject, training and research among dental students and clinicians may be helpful in improving statistical skills.

A recent study in India, reported that although biostatistics was a difficult subject when placed alongside dentistry, the majority agreed that acquiring knowledge about the subject would be beneficial for their career (Batra et al., 2014). Studies on postgraduate dental students showed that they had good ability to write on the statistical section in their scientific writing (Kumar et al., 2014). Despite a clear acceptance of the importance of biostatistics, a study was shown that some medical professionals had a substandard knowledge of it (West \& Ficalora, 2007). Statistical knowledge, when it was taught effectively, can lead to a positive attitude of students and dental professionals towards the subject. As a result, effective interpretation of scientific data could be achieved with their own capability.

Hence, the main rationale of this study was to assess the level of knowledge and perception about biostatistics among dental and medical undergraduate students in order to determine their proficiency in this subject. Evidently, in the light of these findings, we believe that it could provide the means and ways to improve the teaching methods of biostatistics. Moreover, it could enhance the awareness on the importance of biostatistics in improving one's analytical thinking ability, understanding and interpreting statistical results in scientific studies.

\section{Materials and Methods}

A cross-sectional study was carried out among year 4 and year 5 undergraduate dental students and year 4 undergraduate medical students in IIUM Kuantan Campus between March 2020 to March 2021. The study was approved by the IIUM Research Ethics Committee (IREC 2020-040). The sample size was calculated using $G^{*}$ Power software (Ahmad et al., 2018). The calculated sample size based on MannWhitney Test with power $=0.80$, Alpha $=0.05$ and effect size $=0.5$ which lead to the minimum sample size required per group is 67. The minimum sample size required for this study is 134 , however, the current study was carried out among 158 participants. The sample was selected based on the inclusion criteria which were year 4 undergraduate medical students, year 4 and year 5 undergraduate dental students and exclusion criteria for those who did not give consent for the study.

\section{Pilot study}

A pilot study was conducted among 34 undergraduate Year 2 and Year 3 medical students to check the feasibility of the questionnaire and to test the process of distribution of questionnaire as they already undergo the biostatistics lecture during year 1 of their study. Self-administered questionnaires were established by adapting questions from an existing survey (Daher \& Amin, 2010). The questionnaire was given to the students via Google Form platform. The reliability of the questionnaire was then examined using Cronbach's alpha and the result was shown as in Table 1. 
Table 1. Result of questionnaire reliability test

$\begin{array}{ccc}\text { Domain } & \text { Number of Item } & \text { Cronbach's } \boldsymbol{a} \\ \text { Knowledge } & 14 & 0.898 \\ \text { Domain Course Value (A) } & 9 & 0.858 \\ \text { Domain Difficulties (B) } & 11 & 0.694 \\ \text { Domain Behavior (C) } & 5 & 0.927 \\ \text { Domain Expectation (D) } & 11 & 0.817\end{array}$

\section{Study design and questionnaire}

A set of self-administered questionnaires containing consent form, questions regarding demographic details and selfassessment instrument were used for the study. The demographic details were name, age, gender, course, year and possession of personal computer, SPSS software as well as G*Power software. The perceived knowledge and perception towards Biostatistics were assessed by using a selfassessment questionnaire. The responses were graded from 5-points Likert scale. The resulting questionnaire had 50 items. The 50 questions which assessed perceived knowledge (very low $=1$, low $=2$, moderate $=3$ high $=4$ and very high $=5$ ) and perception (strongly disagree $=1$, disagree $=$ 2 , neutral $=3$ agree $=4$ and strongly agree $=$ $5)$ towards the course fell into 5 domains, namely knowledge, course value (A), difficulties (B), behavior (C) and expectation (D).

The knowledge domain was about student's current perceived knowledge regarding the course, especially on the application of biostatistics in research studies. The course value domain was about perceptions of the usefulness, relevance and worth of the subject in professional life. The difficulties domain was about the difficulties faced by the students and factors that may influence interest in the subject. The behaviour domain was about how students perceived lecturer behaviour towards them. Lastly, the expectation domain was about the possible actions that may influence the outcome of the course study. For the result, presentation and interpretation, the Likert scale for perceived knowledge was combined into very low-low, moderate, high-very high and for perception, strongly disagree-disagree, neutral and agree-strongly agree.

\section{Statistical Analysis}

Data was analysed using IBM SPSS version 25. Categorical variables were described by frequencies and percentage. Mann Whitney $\mathrm{U}$ test was used to compare perceived knowledge and perception between dental and medical students. The significance level was set at 0.05 . In order to classify the scores as positive or negative perception, for example the calculation for the domain $\mathrm{C}$ where there are five variables, the maximum score expected will be $25(5 \times 5)$ and the cutoff will be $17.5(5 \times 5 \times 0.7)$. Any score above 17.5 was considered an indicator of positive perception.

\section{Results}

Overall, the questionnaire was a satisfactory level of consistency, reflected by the given reliability coefficient. Items of the (B) behavior domain showed the highest consistency, while the difficulties domain showed the lowest value as shown in Table 1. The characteristics of the study sample were shown in Table 2. A total of 158 out of 190 students responded to the questionnaire yielding a response rate of $83.2 \%$. There were $57 \%$ dental students and $43 \%$ medical students participating in this study which consists of $24.7 \%$ males and $75.3 \%$ females. Almost all the students $(98.1 \%)$ had a personal computer, but only $66.5 \%$ had SPSS computer software. The possession of $\mathrm{G}^{*}$ Power software or other software for sample size calculation was reported to be only $12 \%$. Other than that, $22.5 \%$ of the students know and $77.5 \%$ do not know about biostatistics prior to entering dental and medical programs in 
IIUM. Among them, $41.1 \%$ were able to define biostatistics and $79.7 \%$ of the students knew the usage of biostatistics in their field. Furthermore, almost more than
$70 \%$ of them did consult with their biostatistician and perceived their current level of knowledge in biostatistics was moderate.

Table 2. Characteristics of study sample

\begin{tabular}{|c|c|c|c|}
\hline & $\begin{array}{c}\text { Dental } \\
\text { n (\%) }\end{array}$ & $\begin{array}{l}\text { Medical } \\
\text { n (\%) }\end{array}$ & $\begin{array}{l}\text { Total } \\
\text { n }(\%)\end{array}$ \\
\hline \multicolumn{4}{|l|}{ Gender } \\
\hline Male & $25(27.8)$ & $14(20.6)$ & $39(24.7)$ \\
\hline Female & $65(72.2)$ & $54(79.4)$ & $119(75.3)$ \\
\hline Course of study & $90(57)$ & $68(43)$ & $158(100)$ \\
\hline \multicolumn{4}{|l|}{ Has personal computer } \\
\hline Yes & $88(97.8)$ & $67(98.5)$ & $155(98.1)$ \\
\hline No & $2(2.2)$ & $1(1.5)$ & $3(1.9)$ \\
\hline \multicolumn{4}{|l|}{ Has SPSS software } \\
\hline Yes & $84(93.3)$ & $21(30.9)$ & $105(66.5)$ \\
\hline No & $6(6.7)$ & $47(69.1)$ & $53(33.5)$ \\
\hline \multicolumn{4}{|l|}{ Has G*Power Software } \\
\hline Yes & $11(12.2)$ & $8(11.8)$ & $139(88)$ \\
\hline No & $79(87.8)$ & $60(88.2)$ & $19(12)$ \\
\hline \multicolumn{4}{|c|}{$\begin{array}{l}\text { Do you know about Biostatistics subject } \\
\text { prior to entering dental/medical school? }\end{array}$} \\
\hline Yes & $21(23.3)$ & $14(20.6)$ & $35(22.2)$ \\
\hline Maybe & $8(8.9)$ & $10(14.7)$ & $18(11.4)$ \\
\hline No & $61(67.8)$ & $44(64.7)$ & $105(66.5)$ \\
\hline \multicolumn{4}{|c|}{ Do you able to define Biostatistics? } \\
\hline Yes & $33(36.7)$ & $32(47.1)$ & $65(41.1)$ \\
\hline Maybe & $48(53.3)$ & $32(47.1)$ & $80(50.6)$ \\
\hline No & $9(10)$ & $4(5.9)$ & $13(18.2)$ \\
\hline \multicolumn{4}{|c|}{ Do you know the usage of Biostatistics? } \\
\hline Yes & $66(73.3)$ & $60(88.2)$ & $126(79.7)$ \\
\hline Maybe & $23(25.6)$ & $7(10.3)$ & $30(19)$ \\
\hline No & $1(1.1)$ & $1(1.5)$ & $2(1.3)$ \\
\hline \multicolumn{4}{|c|}{$\begin{array}{l}\text { Perceived current level of knowledge of } \\
\text { Biostatistics }\end{array}$} \\
\hline Very low-Low & $24(26.7 \%)$ & $9(13.2)$ & $33(20.9)$ \\
\hline Moderate & $62(68.9 \%)$ & $52(76.5)$ & $114(72.2)$ \\
\hline Very high-High & $4(4.4 \%)$ & $7(10.3)$ & $11(7)$ \\
\hline \multicolumn{4}{|c|}{ Did you ever consult your biostatistician? } \\
\hline Yes & $35(38.9)$ & $8(11.8)$ & $43(27.2)$ \\
\hline No & $55(61.1)$ & $60(88.2)$ & $115(72.8)$ \\
\hline
\end{tabular}


Responses to each survey question were presented in Table 3 until Table 7. Firstly, looking at the responses regarding their perceived knowledge on biostatistics, the response can be divided into lowest response, very low-low, moderate and highvery high response. It was observed that both the dental and medical students' perceived knowledge on probability and non-probability sampling were more than $60 \%$. However, there was a difference in term of usage of both sampling technique as the medical students perceived more than $60 \%$ compared to dental students. The usage of statistical analysis such as One-way ANOVA, Mann Whitney U test and Kruskal Wallis test presented that the dental students' perceived knowledge were less than $60 \%$ compared to medical students which were more than $60 \%$.

Regarding the course value domain, highest response had been observed which $84.4 \%$ of students from dentistry realized the relevance of the subject to the real health issues at the end of module, $81.1 \%$ thought that the sequencing of the topic was logical and $77.8 \%$ agreed that the gained knowledge and experience were useful to their career. However, only 38.9\% agreed that their skills improved in solving problems, $51.1 \%$ felt that they were confident to do basic statistical and epidemiological analysis and $50.0 \%$ felt they gained skill in designing research. On the other hand, $85.3 \%$ of medical students realized the relevance of biostatistics to the real health issues and $82.4 \%$ medical students gained skill to read scientific papers. Plus, about $79.4 \%$ of the medical students understood the main concepts of biostatistics yet only $63.2 \%$ were confident to do basic statistical analysis. About $64.7 \%$ agreed that the course focused on the concept instead of calculation and $64.7 \%$ found their skill improved in problem solving.

For the difficulties domain, most of the dental and medical students admitted liking clinical studies more than biostatistics (74.4\%-77.9\%) and had a lack of practicing exercise for biostatistics topics (69.1\%73.3\%). They also agreed that biostatistics subjects need creative thinking (66.7\%$69.1 \%$ and must deal with numbers (57.4\%-61.1\%). Furthermore, most of them "strongly disagree" to "disagree" on not seeing the relation between statistics and dentistry or medicine (64.4\%-72.1\%) and lectures were not interesting at this level (55.6\%-63.2\%). However, only $35.6 \%$ of dental students and $42.6 \%$ of medical students simply were not interested in the subject. Other than that, in relation to behavioural domain as shown in the Table 6 , most of the dental and medical students "strongly agree" to "agree" on lecturer were facilitator of instruction who guided the students (91.2\%-93.3\%) and sources of knowledge (92.6\%-93.3\%). Most of them also agreed that they work, and effort were acknowledged (86.7\%-91.2\%) and being treated with respect during of the time they were taking the biostatistics course $(92.6 \%$ $95.6 \%$ ), and they also believe that the responsibility of the student to initiate debate or questions during lectures $173.3 \%$ $77.9 \%)$.

Last but not least for expectation domain, most of the dental and medical students believe that they were in need of more practical and workshop for planning and data collection for the courses (76.5\%$82.2 \%$ ), to be provided specific textbook for biostatistics (60\%-66.2\%), carried out short exam quiz before the progress test (66.2\%$67.8 \%$ ) and lectures should be followed by smaller group session (60\%-70.6\%). They also agreed to emphasise on using biostatistics in their respected courses $(63.3 \%-67.6 \%)$ by giving more time for the whole course (54.4\%-57.8\%) and agreed for attendance to be strictly taken during the computer lab sessions (63.3\%-67.6\%). Nevertheless, only $46.7-47.1 \%$ of the dental and medical students agreed to make the module pure for biostatistics so that the attention will not be withdrawn to other subjects and $42.6 \%-58.9 \%$ agreed to introduce this course as earlier in year two of their studies. Overall, it is observable from Table 8 that most of the dental and medical students were reflecting positive perceptions in course value, behavioural and expectation. 
Table 3. Percentage of dental and medical students' response to questions on perceived biostatistics knowledge

\begin{tabular}{|c|c|c|c|c|c|c|c|}
\hline $\begin{array}{c}\text { Questions } \\
\text { Domain: Knowledge }\end{array}$ & $\begin{array}{l}\text { Very Low- } \\
\text { Low }\end{array}$ & $\begin{array}{l}\text { DENTAL } \\
\text { Moderate }\end{array}$ & $\begin{array}{l}\text { High-Very } \\
\text { High }\end{array}$ & $\begin{array}{l}\text { Very Low- } \\
\text { Low }\end{array}$ & $\begin{array}{l}\text { MEDICAL } \\
\text { Moderate }\end{array}$ & $\begin{array}{l}\text { High-Very } \\
\text { High }\end{array}$ & $\begin{array}{c}p \\
\text { value }\end{array}$ \\
\hline Knowledge on probability sampling method & $19(21.1 \%)$ & $61(67.8 \%)$ & $10(11.1 \%)$ & $5(7.4 \%)$ & $43(63.2 \%)$ & $20(29.4 \%)$ & $0.001^{*}$ \\
\hline Usage of probability sampling method & $29(33.0 \%)$ & $51(58.0 \%)$ & $8(9.1 \%)$ & $8(11.8 \%)$ & $43(63.2 \%)$ & $17(25.0 \%)$ & $0.000^{*}$ \\
\hline $\begin{array}{l}\text { Knowledge on non-probability sampling } \\
\text { method }\end{array}$ & $25(28.1 \%)$ & $54(60.7 \%)$ & $10(11.2 \%)$ & $6(8.8 \%)$ & $45(66.2 \%)$ & $17(25.0 \%)$ & $0.001^{*}$ \\
\hline Usage of non-probability sampling method & $32(36.0 \%)$ & $50(56.2 \%)$ & $7(7.9 \%)$ & $6(13.2 \%)$ & $46(67.6 \%)$ & $16(19.1 \%)$ & $0.001^{*}$ \\
\hline $\begin{array}{l}\text { Knowledge on parametric test } \\
\text { Usage of one Sample t-test }\end{array}$ & $\begin{array}{l}17(18.9 \%) \\
17(18.9 \%)\end{array}$ & $\begin{array}{l}54(60.0 \%) \\
52(57.8 \%)\end{array}$ & $\begin{array}{l}19(21.1 \%) \\
21(23.3 \%)\end{array}$ & $\begin{array}{l}6(8.8 \%) \\
6(8.8 \%)\end{array}$ & $\begin{array}{l}46(67.6 \%) \\
43(63.2 \%)\end{array}$ & $\begin{array}{l}16(23.5 \%) \\
19(27.9 \%)\end{array}$ & $\begin{array}{l}0.214 \\
0.159\end{array}$ \\
\hline Usage of independent t-test & $21(23.3 \%)$ & $48(53.3 \%)$ & $21(23.3 \%)$ & $8(11.8 \%)$ & $39(57.4 \%)$ & $21(30.9 \%)$ & 0.080 \\
\hline $\begin{array}{l}\text { Usage of paired t-test } \\
\text { Usage of Analysis of Variance (ANOVA) }\end{array}$ & $\begin{array}{l}23(25.6 \%) \\
32(35.6 \%)\end{array}$ & $\begin{array}{l}48(53.3 \%) \\
46(51.1 \%)\end{array}$ & $\begin{array}{l}19(21.1 \%) \\
12(13.3 \%)\end{array}$ & $\begin{array}{c}10(14.7 \%) \\
9(13.2 \%)\end{array}$ & $\begin{array}{l}38(55.9 \%) \\
41(60.3 \%)\end{array}$ & $\begin{array}{l}20(29.4 \%) \\
18(26.5 \%)\end{array}$ & $\begin{array}{l}0.079 \\
0.001^{*}\end{array}$ \\
\hline $\begin{array}{l}\text { Knowledge on non-parametric test } \\
\text { Usage of one sample Wilcoxon test }\end{array}$ & $\begin{array}{l}28(31.1 \%) \\
35(38.9 \%)\end{array}$ & $\begin{array}{l}52(57.8 \%) \\
45(50.0 \%)\end{array}$ & $\begin{array}{l}10(11.1 \%) \\
10(11.1 \%)\end{array}$ & $\begin{array}{l}14(20.6 \%) \\
17(25.0 \%)\end{array}$ & $\begin{array}{l}45(66.2 \%) \\
42(61.8 \%)\end{array}$ & $\begin{array}{l}9(13.2 \%) \\
9(13.2 \%)\end{array}$ & $\begin{array}{l}0.179 \\
0.100\end{array}$ \\
\hline Usage of Mann Whitney test & $40(44.4 \%)$ & $43(47.8 \%)$ & $7(7.8 \%)$ & $13(19.1 \%)$ & $43(63.2 \%)$ & $12(17.6 \%)$ & $0.001^{*}$ \\
\hline Usage of Wilcoxon signed rank test & $42(46.7 \%)$ & $40(44.4 \%)$ & $8(8.9 \%)$ & $22(32.4 \%)$ & 37 (54.4\%) & $9(13.2 \%)$ & 0.068 \\
\hline Usage of Kruskal Wallis test & $41(45.6 \%)$ & $40(44.4 \%)$ & $9(10.0 \%)$ & $16(23.5 \%)$ & $41(60.3 \%)$ & $11(16.2 \%)$ & $0.006^{*}$ \\
\hline
\end{tabular}

*Significant at $\mathrm{p}$ value less than $<0.05$ 
Table 4. Frequency and percentage of dental and medical students' response to questions regarding biostatistics course value

\begin{tabular}{|c|c|c|c|c|c|c|c|}
\hline \multirow{2}{*}{$\begin{array}{c}\text { Questions } \\
\text { Domain A: Course Value }\end{array}$} & \multicolumn{3}{|c|}{ DENTAL } & \multicolumn{3}{|c|}{ MEDICAL } & \multirow[b]{2}{*}{$p$ value } \\
\hline & $\begin{array}{c}\text { Strongly } \\
\text { Disagree- } \\
\text { Disagree }\end{array}$ & Neutral & $\begin{array}{l}\text { Agree- } \\
\text { Strongly } \\
\text { Agree }\end{array}$ & $\begin{array}{c}\text { Strongly } \\
\text { Disagree- } \\
\text { Disagree }\end{array}$ & Neutral & $\begin{array}{l}\text { Agree- } \\
\text { Strongly } \\
\text { Agree }\end{array}$ & \\
\hline $\begin{array}{l}\text { The course focuses on the concept of } \\
\text { interpretation more than calculations. }\end{array}$ & $0(0.0 \%)$ & $36(40.0 \%)$ & $54(60.0 \%)$ & $3(4.4 \%)$ & $21(30.9 \%)$ & $44(64.7 \%)$ & 0.708 \\
\hline $\begin{array}{l}\text { I realized the relevance of Biostatistics to } \\
\text { the real health issues. }\end{array}$ & $1(1.1 \%)$ & $13(14.4 \%)$ & $76(84.4 \%)$ & $1(1.5 \%)$ & $9(13.2 \%)$ & $58(85.3 \%)$ & 0.892 \\
\hline Sequencing of topics was logical. & $0(0.0 \%)$ & $17(18.9 \%)$ & $73(81.1 \%)$ & $2(2.9 \%)$ & $18(26.5 \%)$ & $48(70.6 \%)$ & 0.105 \\
\hline $\begin{array}{l}\text { The gained knowledge and experience are } \\
\text { useful to my career as a doctor. }\end{array}$ & $0(0.0 \%)$ & $20(22.2 \%)$ & $70(77.8 \%)$ & $2(2.9 \%)$ & $13(19.1 \%)$ & $53(77.9 \%)$ & 0.942 \\
\hline $\begin{array}{l}\text { I understood the main concepts of } \\
\text { Biostatistics. }\end{array}$ & $3(3.3 \%)$ & $34(37.8 \%)$ & $53(58.9 \%)$ & $2(2.9 \%)$ & $12(17.6 \%)$ & $54(79.4 \%)$ & $0.008^{*}$ \\
\hline I gained skills to read scientific papers. & $7(7.8 \%)$ & $23(25.6 \%)$ & $60(66.7 \%)$ & $1(1.5 \%)$ & $11(16.2 \%)$ & $56(82.4 \%)$ & $0.021^{*}$ \\
\hline My skills improved in solving problems. & $6(6.7 \%)$ & $49(54.4 \%)$ & $36(38.9 \%)$ & $3(4.4 \%)$ & $21(30.9 \%)$ & $44(64.7 \%)$ & $0.002^{*}$ \\
\hline I gained skills to design research. & $4(4.4 \%)$ & $41(45.6 \%)$ & $45(50.0 \%)$ & $3(4.4 \%)$ & $17(25.0 \%)$ & $48(70.6 \%)$ & $0.014^{*}$ \\
\hline $\begin{array}{l}\text { I gained confidence in my ability to do } \\
\text { basic statistical analysis. }\end{array}$ & $7(7.8 \%)$ & $37(41.1 \%)$ & $46(51.1 \%)$ & $3(4.4 \%)$ & $22(32.4 \%)$ & $43(63.2 \%)$ & 0.116 \\
\hline
\end{tabular}

*Significant at $p$ value less than $<0.05$ 
Table 5. Frequency and percentage of dental and medical students' response on difficulties of biostatistics

\begin{tabular}{|c|c|c|c|c|c|c|c|}
\hline $\begin{array}{c}\text { Questions } \\
\text { Domain B: Difficulties }\end{array}$ & $\begin{array}{l}\text { Strongly } \\
\text { Disagree- } \\
\text { Disagree }\end{array}$ & $\begin{array}{l}\text { DENTAL } \\
\text { Neutral }\end{array}$ & $\begin{array}{l}\text { Agree- } \\
\text { Strongly } \\
\text { Agree }\end{array}$ & $\begin{array}{l}\text { Strongly } \\
\text { Disagree- } \\
\text { Disagree }\end{array}$ & $\begin{array}{l}\text { MEDICAL } \\
\text { Neutral }\end{array}$ & $\begin{array}{l}\text { Agree- } \\
\text { Strongly } \\
\text { Agree }\end{array}$ & $p$ value \\
\hline $\begin{array}{l}\text { Lack of practicing exercise for these } \\
\text { topics. }\end{array}$ & $7(7.8 \%)$ & $17(18.9 \%)$ & $66(73.3 \%)$ & $6(8.8 \%)$ & $15(22.1 \%)$ & $47(69.1 \%)$ & 0.571 \\
\hline Too many lectures for one day. & $33(36.7 \%)$ & $45(50.0 \%)$ & $12(13.3 \%)$ & $23(33.8 \%)$ & $33(48.5 \%)$ & $12(17.6 \%)$ & 0.540 \\
\hline Subjects need creative thinking. & $6(6.7 \%)$ & $24(26.7 \%)$ & $60(66.7 \%)$ & $4(5.9 \%)$ & $17(25.0 \%)$ & $47(69.1 \%)$ & 0.738 \\
\hline Lectures are difficult to understand. & $23(25.6 \%)$ & $36(40.0 \%)$ & $31(34.4 \%)$ & $28(41.2 \%)$ & $32(47.1 \%)$ & $8(11.8 \%)$ & $0.002^{*}$ \\
\hline $\begin{array}{l}\text { I like clinical studies more than } \\
\text { biostatistics. }\end{array}$ & $4(4.4 \%)$ & $19(21.1 \%)$ & $67(74.4 \%)$ & $6(8.8 \%)$ & $9(13.2 \%)$ & $53(77.9 \%)$ & 0.749 \\
\hline Lectures are lengthy. & $25(27.8 \%)$ & $47(52.2 \%)$ & $18(20.0 \%)$ & $24(35.3 \%)$ & $37(54.4 \%)$ & $7(10.3 \%)$ & 0.121 \\
\hline There are no specific references. & $18(20.0 \%)$ & $42(46.7 \%)$ & $30(33.3 \%)$ & $28(41.2 \%)$ & $22(32.4 \%)$ & $18(26.5 \%)$ & $0.025^{*}$ \\
\hline I must deal with numbers. & $7(7.8 \%)$ & $28(31.1 \%)$ & $55(61.1 \%)$ & $9(13.2 \%)$ & $20(29.4 \%)$ & $39(57.4 \%)$ & 0.491 \\
\hline I am simply not interested in this subject. & $21(23.3 \%)$ & $37(41.1 \%)$ & $32(35.6 \%)$ & $14(20.6 \%)$ & $25(36.8 \%)$ & $29(42.6 \%)$ & 0.407 \\
\hline $\begin{array}{l}\text { I cannot see the relation between } \\
\text { statistics and dentistry/medicine at this } \\
\text { level. }\end{array}$ & 58 (64.4\%) & $23(25.6 \%)$ & $9(10.0 \%)$ & $49(72.1 \%)$ & 12 (17.6\%) & 7 (10.3\%) & 0.378 \\
\hline Lectures are not interesting. & $50(55.6 \%)$ & $33(36.7 \%)$ & $7(7.8 \%)$ & $43(63.2 \%)$ & $18(26.5 \%)$ & $7(10.3 \%)$ & 0.463 \\
\hline
\end{tabular}

*Significant at $p$ value less than $<0.05$ 
Table 6. Frequency and percentage of dental and medical students' response on their behaviour towards biostatistics

\begin{tabular}{|c|c|c|c|c|c|c|c|}
\hline $\begin{array}{l}\text { Questions } \\
\text { Domain C: Behavioural }\end{array}$ & $\begin{array}{l}\text { Strongly } \\
\text { Disagree- } \\
\text { Disagree }\end{array}$ & $\begin{array}{l}\text { DENTAL } \\
\text { Neutral }\end{array}$ & $\begin{array}{l}\text { Agree- } \\
\text { Strongly } \\
\text { Agree }\end{array}$ & $\begin{array}{l}\text { Strongly } \\
\text { Disagree- } \\
\text { Disagree }\end{array}$ & $\begin{array}{l}\text { MEDICAL } \\
\text { Neutral }\end{array}$ & $\begin{array}{l}\text { Agree- } \\
\text { Strongly } \\
\text { Agree }\end{array}$ & $p$ value \\
\hline $\begin{array}{l}\text { Lecturer is the facilitator of instruction } \\
\text { \& guiding students. }\end{array}$ & $0(0.0 \%)$ & $6(6.7 \%)$ & $84(93.3 \%)$ & $2(2.9 \%)$ & $4(5.9 \%)$ & $62(91.2 \%)$ & 0.582 \\
\hline Lecturer is the source of knowledge. & $0(0.0 \%)$ & $6(6.7 \%)$ & $84(93.3 \%)$ & $2(2.9 \%)$ & $3(4.4 \%)$ & $63(92.6 \%)$ & 0.830 \\
\hline I am treated with respect. & $0(0.0 \%)$ & $4(4.4 \%)$ & $86(95.6 \%)$ & $2(2.9 \%)$ & $3(4.4 \%)$ & $63(92.6 \%)$ & 0.416 \\
\hline My work and efforts are acknowledged. & $0(0.0 \%)$ & $12(3.3 \%)$ & $78(86.7 \%)$ & $1(1.5 \%)$ & $5(7.4 \%)$ & $62(91.2 \%)$ & 0.400 \\
\hline $\begin{array}{l}\text { It is the responsibility of the students to } \\
\text { initiate debate/question during } \\
\text { lectures. }\end{array}$ & $2(2.2 \%)$ & $22(24.4 \%)$ & $66(73.3 \%)$ & $2(2.9 \%)$ & $13(19.1 \%)$ & $53(77.9 \%)$ & 0.536 \\
\hline
\end{tabular}


Table 7. Frequency and percentage of dental and medical students' expectations regarding biostatistics

\begin{tabular}{|c|c|c|c|c|c|c|c|}
\hline \multirow[b]{2}{*}{$\begin{array}{l}\text { Questions } \\
\text { Domain D: Expectations }\end{array}$} & \multirow[b]{2}{*}{$\begin{array}{l}\text { Strongly } \\
\text { Disagree- } \\
\text { Disagree }\end{array}$} & \multicolumn{2}{|l|}{ DENTAL } & \multicolumn{3}{|c|}{ MEDICAL } & \multirow[b]{2}{*}{$p$ value } \\
\hline & & Neutral & $\begin{array}{l}\text { Agree- } \\
\text { Strongly } \\
\text { Agree }\end{array}$ & $\begin{array}{l}\text { Strongly } \\
\text { Disagree- } \\
\text { Disagree }\end{array}$ & Neutral & $\begin{array}{l}\text { Agree- Strongly } \\
\text { Agree }\end{array}$ & \\
\hline $\begin{array}{l}\text { Need more practical, workshop for planning } \\
\text { and data collection to have real experience in } \\
\text { dealing with data. }\end{array}$ & $0(0.0 \%)$ & $16(17.8 \%)$ & $74(82.2 \%)$ & $2(2.9 \%)$ & $14(20.6 \%)$ & $52(76.5 \%)$ & 0.333 \\
\hline Provide specific textbooks for biostatistics. & $2(2.2 \%)$ & $34(37.8 \%)$ & $54(60.0 \%)$ & $5(7.4 \%)$ & $18(26.5 \%)$ & $45(66.2 \%)$ & 0.613 \\
\hline $\begin{array}{l}\text { Carry out shorts exam (quiz) before the } \\
\text { progress test to evaluate the understanding of } \\
\text { the student. }\end{array}$ & $5(5.6 \%)$ & $24(26.7 \%)$ & $61(67.8 \%)$ & $5(7.4 \%)$ & $18(26.5 \%)$ & $45(66.2 \%)$ & 0.785 \\
\hline $\begin{array}{l}\text { The lecture should be followed by smaller } \\
\text { grouping session. }\end{array}$ & $4(4.4 \%)$ & $32(35.6 \%)$ & $54(60.0 \%)$ & $3(4.4 \%)$ & $17(25.0 \%)$ & $48(70.6 \%)$ & 0.194 \\
\hline Give more time for the whole course. & $7(7.8 \%)$ & $31(34.4 \%)$ & $52(57.8 \%)$ & $9(13.2 \%)$ & $22(32.4 \%)$ & $37(54.4 \%)$ & 0.511 \\
\hline $\begin{array}{l}\text { Emphasize on using biostatistics in your } \\
\text { courses. }\end{array}$ & $5(5.6 \%)$ & $28(31.1 \%)$ & $57(63.3 \%)$ & $4(5.9 \%)$ & $18(26.5 \%)$ & $46(67.6 \%)$ & 0.611 \\
\hline $\begin{array}{l}\text { Attendance to be strictly taken during the } \\
\text { computer lab session. }\end{array}$ & $5(5.6 \%)$ & $27(30.0 \%)$ & $58(64.4 \%)$ & $4(5.9 \%)$ & $22(32.4 \%)$ & $42(61.8 \%)$ & 0.737 \\
\hline $\begin{array}{l}\text { Make the module pure for biostatistics, so the } \\
\text { attention will not be withdrawn to other } \\
\text { subjects. }\end{array}$ & $11(12.2 \%)$ & $37(41.1 \%)$ & $42(46.7 \%)$ & $13(19.1 \%)$ & $23(33.8 \%)$ & $42(47.1 \%)$ & 0.696 \\
\hline Introduce this course earlier in year two. & $15(16.7 \%)$ & $22(24.4 \%)$ & $53(58.9 \%)$ & $5(7.4 \%)$ & $34(50.0 \%)$ & $29(42.6 \%)$ & 0.248 \\
\hline I must study at home before class meetings. & $4(4.4 \%)$ & $31(34.4 \%)$ & $55(61.1 \%)$ & $4(5.9 \%)$ & $20(29.4 \%)$ & $44(64.7 \%)$ & 0.716 \\
\hline $\begin{array}{l}\text { Disconnect the internet during the lab session } \\
\text { to avoid distraction. }\end{array}$ & $29(32.2 \%)$ & $32(35.6 \%)$ & $29(32.2 \%)$ & $24(35.3 \%)$ & $28(41.2 \%)$ & $16(23.5 \%)$ & 0.362 \\
\hline
\end{tabular}


Table 8. Frequency distribution of positive perception

\begin{tabular}{lll} 
& \multicolumn{2}{c}{ Positive perception } \\
& No & Yes \\
\hline $\begin{array}{l}\text { A: Course Value } \\
\text { Dentistry }\end{array}$ & $23(25.36)$ & $67(74.4)$ \\
Medical & $14(20.6)$ & $54(79.4)$ \\
B: Difficulties & & \\
Dentistry & $71(78.9)$ & $19(21.1)$ \\
Medical & $54(79.4)$ & $14(20.6)$ \\
C: Behavioral & & \\
$\quad$ Dentistry & $6(6.7)$ & $84(93.3)$ \\
Medical & $4(5.9)$ & $64(94.1)$ \\
D: Expectation & & \\
$\quad$ Dentistry & $35(38.9)$ & $55(61.1)$ \\
Medical & $30(44.1)$ & $38(55.9)$
\end{tabular}

\section{Discussion}

The significance of biostatistics was recognized completely in different dental and medical schools in both developed and developing countries (Chaoubah, 2021; Bourzgui et al., 2019; Sami, 2010). Nevertheless, there are a variety of existence biostatistics in dental and medical from school to school with respect to the distributed time, scope and topic covered. In this study, the level of perceived knowledge and perception of dental and medical students regarding biostatistics was assessed and compared among the dental and medical undergraduate students. In the present study, a significant difference was seen among dental and medical students for the level of perceived knowledge in biostatistics. It was observed that medical students had slightly better perceived knowledge about biostatistics than the In this study, there was also a significant difference among IIUM dental and medical undergraduate students for the level of perception in the course value domain. Majority of the medical students showed positive perception regarding course value compared to dental students in understanding the main concepts of the course, reading scientific papers, designing research and improved skill in solving problems. This result was also in agreement with a study done by Daher \& Amin (2010) dental students in the knowledge of probability, non-probability sampling method and usage of probability sampling, non-probability sampling, ANOVA, Mann Whitney $U$ test and Kruskal Wallis test. However, there were no significant differences observed for the others' perceived knowledge and usage on statistical analysis. As an insight, the medical students were exposed to the biostatistics course during year 1 block four of their study where for the whole 4 weeks, they focused only on biostatistics which include both theory and practical. In contrast, the dental students were exposed to a biostatistics course for the whole year 4 . However, there was no designated week where they would be focusing on biostatistics only. The study also in line with previous research that medical students had perceived better biostatistics knowledge (Ercan et al., 2008).

and Abou Dargham et al. (2021) where more than half of undergraduate medical students showed they understood the main concept of the courses. However, the skill to design research, read scientific papers and solve the problem for the medical students were consistent with our current study for the dental students (Daher \& Amin, 2010; Abou Dargham et al. 2021). Nevertheless, more than half of the dental (51.1\%) and medical $(63.2 \%)$ students gained confidence in their ability to do basic statistical analysis 
compared to other studies by Daher \& Amin (2010) and Abou Dargham et al. (2021) which are less than $40 \%$.

Other than that, there was a significant difference among dental and medical students for difficulties in understanding the lectures where $34.4 \%$ of the dental students agreed that lectures were difficult to understand. In contrast, only $11.8 \%$ of medical students agreed that the lectures were difficult to understand. This was in line with the other study where $61.6 \%$ of the medical students stated it were difficult to understand the lectures (Daher \& Amin, 2010). From the current findings, students found there were no specific references may be due to lack of resources that were suggested by the lecturers for the students to refer to. Thus, this had caused the students to rely solely on what the lecturer provided. It was also reported by the other studies that more than $50 \%$ of the students agreed that no specific references were provided (Daher \& Amin, 2010; Abou Dargham et al., 2021).

Moreover, there was no significant difference observed between dental and medical students in behaviour and expectation domain. As both dental and medical students showed positive perception as the lecturer was the facilitator and source of knowledge for them. They also agreed that their work and effort are acknowledged and treated with respect during the courses. This study was also coherent with the other studies (Daher \& Amin,2010; Abou Dargham et al., 2021). Furthermore, for the expectation domain most of the dental and medical students need more practical classes in dealing with the data, the need to provide specific textbooks and carry out short quizzes while the lecturer should follow up by creating small grouping sessions and giving more time for the whole courses. The finding of this study was also in line with other studies by Shetty et al. (2015), Chima et al. (2015) and Hood \& Neummann (2013).

\section{Limitation}

There were several limitations of this study. Firstly, although there were slight differences in the level of perceived knowledge between IIUM undergraduate dental and medical students, there was no relation to the students' academic performances. This may have a possible effect on the reported perception. Second, there were no open comments given. This feature of open comments may allow improvements to be done on our ends by looking from the students' perspectives thus, improving the exposure of biostatistics to the students.

\section{Conclusion}

In a nutshell, this study concludes that undergraduate dental students have almost similar and moderate level of knowledge in biostatistics as compared to the medical students However, it is important to have additional practice and training through workshop to improve their level of comprehension in biostatistics.

\section{Acknowledgement}

The authors acknowledge the administration of Kulliyyah of Medicine (KOM) and all Year 4 KOM undergraduate students, administration of Kulliyyah of Dentistry (KOD) and all Year 4 and Year 5 KOD undergraduate students for their help in the data collection.

\section{Financial support and sponsorship Nil}

\section{Conflict of interest}

There is no conflict of interest.

\section{References}

Abou Dargham, N., Sultan, Y., Mourad, O., Baidoun, M., Aboul Hosn, O., El Naga, A.A., Bahmad, H.F., Azakir, B. (2021). Perception of biostatistics by Lebanese medical students: a cross-sectional study. Alexandria Journal of Medicine, 57(1),103-109.

Ahmad, W.M.A.W., Ibrahim, M.S.M., Adam, H., Khamis, M.F. (2018). Sample size calculations made easy using $G^{*}$ Power. Penerbit USM, Universiti Sains Malaysia. ISBN 978-967-461-255-9.

Batra, M., Gupta, M., Dany. S.S., Rajput, P. (2014). Perception of dental professionals towards biostatistics. International Scholarly Research Notices. Hindawi Publishing Corporation. 
Bourzgui, F., Abidine, Z., Diouny, S., Serhier, Z., Bennani, O.M. (2019). Assessment of knowledge, perception regarding biostatistics and interpretation of research among Moroccan Dental professionals. International Journal of Dentistry Research, 4(2), 49-54.

Chaoubah, A. (2021). The important role played by Biostatistics in Health professionals' training. Revista Brasileira de Oftalmologia, 80(2), 89-90.

Chima, S.C., Nkwanyana, N.M., Esterhuizen, T.M. (2015). Impact of a short biostatistics course on knowledge and performance of postgraduate scholars: Implications for training of African doctors and biomedical researchers. Nigerian Journal of Clinical Practice, 18, 62-70.

Daher, A.M., Amin, F. (2010). Assessing the perceptions of a biostatistics and epidemiology module: Views of Year 2 medical students from a Malaysian university. A cross-sectional survey. BMC Medical Education, 10(34).

Ercan, I., Ozkaya, G., Ocakoglu, G., Yazici, B., Sezer, A., Ediz, B., et al. (2008). determining biostatistics knowledge of students and physicians in Medical School. Faculty of Medicine, Uludag University Anadolu University, Turkey. Available from: https://www.researchgate.net/publication/2285 00164_Determining_Biostatistics_Knowledge_of_S tudents_and_Physicians_in_Medical_School.

Hood, M., Neumann, D.L. (2013). Evaluation of a workshop to reduce negative perceptions of statistics in undergraduate psychology students. Psychology Learning and Teaching,12, 115-125.

Kumar, L., Shahnawaz, K., Choudhary, S.K., Sarker, G., Barman, S.K., Singh, J.B. (2014). Attitudes toward biostatistics among postgraduate medical students in Kishanganj, Bihar. Journal of Evolution of Medical and Dental Sciences, 3(3), 758-761.

Li, C., Wang, L., Zhang, Y., Li, C., Xu, Y., Shang, L., Xia, J. (2018). Assessment of a block curriculum design on medical postgraduates' perception towards biostatistics: a cohort study. BMC Medical Education, 18(1).

Penmetsa, G.S., Dubba, K., Mohammad, Z. (2017). Knowledge, attitude and perception regarding biostatistics among postgraduate students in dental institutions of Andhra Pradesh. Journal of Indian Association of Public Health Dentistry, 15, 68-72.

Pimenta, R., Faria, B.M., Pereira, I., Vieira, M. (2010). Comparison of attitudes towards statistics in graduate and undergraduate health sciences' students. Proceedings of the Eighth International Conference on Teaching Statistics (ICOTS8), International Association of Statistical Education (IASE).

Sami, W. (2010). Biostatistics education for undergraduate medical students. Biomedica, 26, 80-85.

Shetty, A.C., Al-Rasheed, N.M., Albwardi, S.A. (2015). Dental professionals' attitude towards biostatistics. Journal of Dentistry and Oral Hygiene, 7(7), 113-118.

Sujatha, B.K., Reddy, M.N.T., Vijayan, S. (2018). Assessment of knowledge, attitude, and perception about biostatistics among faculty and postgraduate students in a dental institution, Bengaluru City. Journal of Dental Research and Review, 5(54).

West, C.P., Ficalora, R.D. (2007). clinicians attitudes towards biostatistics. Mayo Foundation for Medical Education and Research, 82(8), 939-943. 